\title{
Effect of Different Weed Management Practices on Nutrient Removal, Nutrient Uptake and Grain Yield of Transplanted Rice (Oryza sativa L.) under Sodic Soil Ecosystem
}

\author{
G. Manisankar*, T. Ramesh and S. Rathika \\ Department of Agronomy, Anbil Dharmalingam Agricultural College and Research Institute, \\ Tamil Nadu Agricultural University, Trichy - 620027, India \\ *Corresponding author
}

\section{Keywords}

Weed management, transplanted rice, sodic soil, nutrient uptake, nutrient removal, pre plant application, glyphosate, glufosinate ammonium, halosulfuron methyl

Article Info

Accepted: 12 April 2021 Available Online: 10 May 2021
A field experiment was carried out at Department of Agronomy, Anbil Dharmalingam Agricultural College and Research Institute, Trichy during Rabi, 2018 to study the effect of different weed management practices on nutrient removal, nutrient uptake andgrain yield of transplanted rice. The experiment was laid out in split plot design with four main plot and five sub plot treatments and replicated thrice. The experimental plot size was 20 $\mathrm{m}^{2}$. Main plot treatments were pre plant application of herbicides namely, glyphosate 2.5 $\mathrm{kg} \mathrm{ha}^{-1}$, glufosinate ammonium $1.0 \mathrm{~kg} \mathrm{ha}^{-1}$,halosulfuron methyl $67.5 \mathrm{~g} \mathrm{ha}^{-1}$ and control. Sub plot treatments consisted of different weed management practices in transplanted rice namely, pre emergence application of bensulfuron methyl + pretilachlor $660 \mathrm{~g} \mathrm{ha}^{-1}$ on 3 DAT + one hand weeding on 45 DAT, post emergence application of bispyribac sodium $25 \mathrm{~g} \mathrm{ha}^{-1}$ on $15 \mathrm{DAT}+$ one hand weeding on $45 \mathrm{DAT}$, application of bensulfuron methyl + pretilachlor $660 \mathrm{~g} \mathrm{ha}^{-1}$ on 3 DAT + bispyribac sodium $25 \mathrm{~g} \mathrm{ha}^{-1}$ on $25 \mathrm{DAT}$, hand weeding twice at 25 and 45 DAT and unweeded control. Pre plant herbicides sprayed 15 days before puddling. The rice variety TRY 3 was grown during the course of investigation. Pre plant application of glyphosate $2.5 \mathrm{~kg} \mathrm{ha}^{-1}$ recorded significantly lower total weed density $\left(18.1\right.$ and $\left.16.7 \mathrm{~m}^{-2}\right)$, lower total weed dry weight $\left(14.5\right.$ and $\left.15.0 \mathrm{~g} \mathrm{~m}^{-2}\right)$ at 40 and 60 DAT respectively, lesser nutrient removal by weeds $\left(6.25,1.33\right.$ and $5.36 \mathrm{NPK} \mathrm{kg} \mathrm{ha}^{-1}$, respectively at $40 \mathrm{DAT})$, higher nutrient uptake by crops $(124.6,32.3$ and $81.5 \mathrm{NPK} \mathrm{kg}$ ha ${ }^{1}$, respectively at maturity), higher dry matter production $\left(11517 \mathrm{~kg} \mathrm{ha}^{-1}\right)$ and higher grain yield(4232 $\left.\mathrm{kg} \mathrm{ha}^{-1}\right)$ than halosulfuron methyl and control. These results are closely followed by glufosinate ammonium $1.0 \mathrm{~kg} \mathrm{ha}^{-1}$.Among the weed management practices fallowed in transplanted rice, hand weeding twice on 25 and 45 DAT resulted significantly lower total weed density $\left(11.8\right.$ and $\left.9.4 \mathrm{~m}^{-2}\right)$, lower total weed dry weight $\left(8.9\right.$ and $6.9 \mathrm{~g} \mathrm{~m}^{-}$ $\left.{ }^{2}\right)$ at 40 and 60 DAT respectively, lesser nutrient removal by weeds $(3.84,0.81$ and 3.29 NPK kg ha ${ }^{-1}$, respectively at 40 DAT), higher nutrient uptake by crops $(130.6,33.8$ and $86.4 \mathrm{NPK} \mathrm{kg} \mathrm{ha}{ }^{-1}$, respectively at maturity) and higher dry matter production (12075 kg ha ${ }^{-}$ $\left.{ }^{1}\right)$ than other treatments. Higher grain yield $\left(4327 \mathrm{~kg} \mathrm{ha}^{-1}\right)$ was obtained with post emergence application of bispyribac sodium $25 \mathrm{~g} \mathrm{ha}^{-1}$ on 15 DAT + one hand weeding on 45 DAT. 


\section{Introduction}

Rice (Oryza sativa L.) is the staple food for more than 60 per cent of the world population and its cultivation secures a livelihood for more than two billion people. In India, rice is grown in an area of 43.79 million hectare with a production of 112.91 million tonnes and an average productivity of 2.5 tonnes hectare ${ }^{1}$ (Anonymous, 2018). In Tamil Nadu, rice is grown in an area of 1.85 million hectares with a production of 6.95 million tonnes and an average productivity of 3.7 tonnes hectare ${ }^{1}$ (Anonymous, 2019).

Weeds are the major biotic constraint to reduce the rice productivity in worldwide. In transplanted rice, about $60 \%$ of the weeds emerge in the period of one week to one month after transplanting. These emerging weeds are competing with rice during effective tillering stage and decline the quantity of panicles leads to reduction in grain yield (Soe thura, 2010). In transplanted rice, $45-51 \%$ yield reduction caused by weeds (Veeraputhiran and Balasubramanian, 2013).

In Rabi season rice (Sep - Jan), where one rice crop is being grown per year and rest of the period, the fields are left as fallow, weeds grown enormously during off season and poses serious threat in reducing the grain yield of rice. Rainfall during August-September months and soaking of main field during nursery period causes more weeds infestation and multiplication. Cyperus rotundus is one of the dominant weeds of sodic soil causes difficulty in land preparation for rice cultivation (Revathi et al., 2017).

In addition, regeneration of Cyperus rhizomes and weeds infestation occur during early growth stages of rice due to improper land leveling and alternate wetting and drying irrigation pattern causes more weeds growth, which leads to reduction in yield of rice.
Weed management can be achieved either application of pre emergence or post emergence or combination of both or manual weeding. Hand weeding is an effective method of weed management in transplanted rice, increasing labourer cost and scarcity of labourer during critical period of agricultural operation lead to the search for alternative methods. Hence, pre plant application of herbicide can be used for controlling the emerged weeds particularly Cyperus before transplanting which facilitate easy land preparation and less weeds in the rice field. Chemical method was most effective, economical way of weed management (Suresh kumar and Durairaj, 2016).

Pre plant application of herbicide provide weed free condition during initial stage because it arrest the germination of weeds. In transplanted rice, later emerged weed makes serious problem during critical period of crop weed competition. Hence, use of pre emergence or post emergence herbicides or combination of both essential for reduce crop weed interference. It is highly essential to control the weeds in transplanted rice through sequential application of herbicides. Very fewer studies have been done on nutrient removal, nutrient uptake and grain yield of transplanted rice using sequential application of herbicides. Hence, present experiment has been carried out to evaluate the different weed management practices on nutrient removal, nutrient uptake and grain yield of transplanted rice under sodic soil ecosystem.

\section{Materials and Methods}

A field experiment was conducted at Department of Agronomy, Anbil Dharmalingam Agricultural College and Research Institute, Tamil Nadu Agricultural University, Tiruchirappalli during Rabi, 2018. The total rainfall received during cropping season was $234 \mathrm{~mm}$ in 12 rainy days. The 
mean maximum and minimum temperature prevailed during the cropping period were $31.8^{\circ} \mathrm{C}$ and $22.7^{\circ} \mathrm{C}$, respectively. The mean relative humidity was 87 and $61 \%$ during forenoon and afternoon, respectively.

The mean bright sunshine hours, evaporation and wind velocity were 6.3 hours day ${ }^{-1}, 3.3$ $\mathrm{mm}$ day $^{-1}$ and $3.8 \mathrm{~km} \mathrm{hr}^{-1}$, respectively.

The soil of the experimental field was alkaline in nature (pH-9.1), sandy clay loam in texture, moderately drained and classified as Vetric Ustropept. The experimental soil was low in available nitrogen $\left(112.9 \mathrm{~kg} \mathrm{ha}^{-1}\right)$, medium in available phosphorus (14.2 $\left.\mathrm{kg} \mathrm{ha}^{-1}\right)$ and high in available potassium $\left(288.4 \mathrm{~kg} \mathrm{ha}^{-1}\right)$.

The experiment was laid out in split plot design with four main plot and five sub plot treatments and replicated thrice. The experimental plot size was $20 \mathrm{~m}^{2}$. Main plot treatments were pre plant application of herbicides namely glyphosate $2.5 \mathrm{~kg} \mathrm{ha}^{-1}$, glufosinate ammonium $1.0 \mathrm{~kg} \mathrm{ha}$ and halosulfuron methyl $67.5 \mathrm{~g} \mathrm{ha}^{-1}$ and control. Sub plot treatments consisted of different weed management practices in transplanted rice namely, pre emergence application of bensulfuron methyl + pretilachlor $660 \mathrm{~g} \mathrm{ha}^{-1}$ on 3 DAT + one hand weeding on 45 DAT, post emergence application of bispyribac sodium $25 \mathrm{~g} \mathrm{ha}^{-1}$ on $15 \mathrm{DAT}+$ one hand weeding on 45 DAT, application of bensulfuron methyl + pretilachlor $660 \mathrm{~g} \mathrm{ha}^{-1}$ on 3 DAT + bispyribac sodium $25 \mathrm{~g} \mathrm{ha}^{-1}$ on 25 DAT, hand weeding twice at 25 and 45 DAT and unweeded control. Pre plant herbicides sprayed 15 days before puddling.

The rice variety TRY 3 was grown during the course of investigation. All the agronomic practises and plant protection measures were adopted as per the recommended package of Tamil Nadu Agricultural University, Coimbatore (CPG, 2012).

\section{Weed density and dry weight}

Total weed density and weed dry weight were recorded at 40 and 60 days after transplanting (DAT) and were subjected to square root $\mathrm{x}+0.5$ transformation before statistical analysis to normalize their distribution.

\section{Nutrient removal and uptake}

Crop nutrient uptake and weeds removal were calculated by multiplying nutrient concentration and dry matter production and denoted as $\mathrm{kg} \mathrm{ha}^{-1}$.

\section{Dry matter production}

Randomly selected five hills from each plot in sampling rows and uprooted. Samples were shade dried and oven dried at $80^{\circ} \mathrm{C}$ for $72 \mathrm{hrs}$. From the dry weight of samples, DMP was estimated and expressed in $\mathrm{kg} \mathrm{ha}^{-1}$.

\section{Grain yield}

Grains harvested from the net plot area was thrashed, cleaned, sun dried and weighed at 14 $\%$ moisture and expressed as $\mathrm{kg} \mathrm{ha}^{-1}$.

\section{Statistical analysis}

The data were statistically analysed following the procedure given by Panse and Sukhatme (1967) for split plot design. CD at $5 \%$ probability was calculated.

\section{Results and Discussion}

\section{Weed flora}

Common weed species observed in the field during the course of investigation were Echinochloa colona (L.), Cynodon dactylon (L.) in grasses, Cyperus rotundus (L.) in sedges and Eclipta alba (L.), Euphorbia prostrata (L.), Lippia nodiflora (L.) in broad 
leaved weeds (BLW). Before spraying of pre plant herbicides, sedges $(71 \%)$ was found to be the predominant category followed by grasses $(18 \%)$ and broad leaved weeds (BLW) (11\%). Cyperus rotundus is one of the dominant weed in sodic soil environment and similar weed species have been found in transplanted rice under sodic soil (Revathi et al., 2017). In transplanted rice, grasses (65.4 $\%$ ) was the dominant weed, followed by sedges $(30.1 \%)$ and BLW $(4.5 \%)$ at 60 DAT in absolute control. This might be due to pre plant application of glyphosate and glufosinate ammonium completely destroyed the weeds before transplanting and also reduced the weeds germination as well as re-growth of Cyperus in rice field.

\section{Total weed density and dry weight}

Pre plant application of glyphosate $2.5 \mathrm{~kg} \mathrm{ha}^{-1}$ registered significantly lower total weed density (18.1 and $16.7 \mathrm{~m}^{-2}$ ) and dry weight (14.5 and $15.0 \mathrm{~g} \mathrm{~m}^{-2}$ ) than others at 40 and 60 DAT, respectively (Table 1). Glyphosate 2.5 $\mathrm{kg} \mathrm{ha}^{-1}$ at 15 days before puddling effectively controlled all the weeds including Cyperus by inhibiting 5-enol pyruvyl shikimate-3phosphate (EPSP) synthase pathway that required for protein synthesis. Further complete drying and incorporation of weeds during puddling would have reduced the weed germination. Such beneficial effect of glyphosate on weed control in transplanted rice has been reported by Ramachandra et al., (2014).This was followed by application of glufosinate ammonium $1.0 \mathrm{~kg} \mathrm{ha}^{-1}$ which recorded the total weed density (28.3 and 25.0 $\mathrm{m}^{-2}$ ) and dry weight (18.1 and $17.2 \mathrm{~g} \mathrm{~m}^{-2}$ ) at 40 and 60 DAT, respectively. Glufosinate inhibited the activity of glutamine synthase led to destroy cells directly by inhibited photosystem I and photosystem II reactions caused complete drying of weeds including Cyperus, which resulted in less weed density and dry weight in transplanted rice (Ellis et al., 2003). Application of halosulfuron methyl $67.5 \mathrm{gha}^{-1}$ registered significantly higher total weed density ( 47.5 and $48.5 \mathrm{~m}^{-2}$ ) and dry weight (25.0 and $29.3 \mathrm{~g} \mathrm{~m}^{-2}$ ) than glyphosate and glufosinate ammonium at 40 and 60 DAT, respectively. The control plot registered significantly higher total weed density (55.3 and $75.7 \mathrm{~m}^{-2}$ ) and dry weight (66.4 and 128.3 $\mathrm{g} \mathrm{m}^{-2}$ ) at 40 and 60 DAT, respectively as compared to other treatments.

Among the weed management practices fallowed in transplanted rice, hand weeding twice at 25 and 45 DAT registered significantly lower total weed density (11.8 and $9.4 \mathrm{~m}^{-2}$ ) and dry weight ( 8.9 and $6.9 \mathrm{~g} \mathrm{~m}^{-}$ ${ }^{2}$ ) at 40 and 60 DAT, respectively. Manual weeding removed all type of weeds including sedges and rice mimicry weeds which had grown along with rice, was the reason behind less weed population and dry weight (Revathi et al., 2017). This was on par with application of bensulfuron methyl + pretilachlor $660 \mathrm{~g} \mathrm{ha}^{-}$ ${ }^{1}$ on 3 DAT + bispyribac sodium $25 \mathrm{~g} \mathrm{ha}^{-1}$ on 25 DAT and post emergence application of bispyribac sodium $25 \mathrm{~g} \mathrm{ha}^{-1}$ on 15 DAT + one hand weeding on 45 DAT. Pre emergence application of bensulfuron methyl + pretilachlor and post emergence application of bispyribac sodium controlled broad spectrum of weeds including grasses, sedges and broadleaved weeds through acetolactate synthase mode of action respectively during critical period of crop weed competition. Hence it recorded lesser total weed density and dry weight.

This finding was close conformity with that of Nivetha et al., (2017) who reported the lesser weed density and dry weight on 60 DAT in transplanted rice with pre emergence application of bensulfuron methyl + pretilachlor followed by early post emergence application of bispyribac sodium. Significantly higher total weed density (116.8 and $\left.144.9 \mathrm{~m}^{-2}\right)$ and dry weight (106.4 and 
$195.4 \mathrm{~g} \mathrm{~m}^{-2}$ ) registered with unweeded control at 40 and 60 DAT, respectively as compared to other treatments.

\section{Nutrient removal by weeds}

Sequential application of herbicides had a significant effect on nutrient removal in transplanted rice (Table 2). Pre plant application of glyphosate $2.5 \mathrm{~kg} \mathrm{ha}{ }^{-1}$ registered significantly lower nitrogen (6.25 and $6.47 \mathrm{~kg} \mathrm{ha}^{-1}$ ), phosphorous (1.33 and 1.37 $\mathrm{kg} \mathrm{ha}^{-1}$ ) and potassium (5.36 and $1.73 \mathrm{~kg} \mathrm{ha}^{-1}$ ) removal by weeds than halosulfuron methyl and controlon 40 and 60 DAT, respectively. Application of glyphosate caused complete drying of weeds including Cyperus within 5 days after application and incorporated during puddling followed by very few weeds encountered after transplanting of rice resulted in lower nutrient removal by weeds. Similar findings were reported by Veeraputhiran and Balasubramanian (2010). However, this was on par with glufosinate ammonium $1.0 \mathrm{~kg} \mathrm{ha}$ 1 . Halosulfuron methyl $67.5 \mathrm{~g} \mathrm{ha}^{-1}$ registered significantly higher nitrogen (10.78 and 12.63 $\mathrm{kg} \mathrm{ha}^{-1}$ ), phosphorous (2.29 and $2.68 \mathrm{~kg} \mathrm{ha}^{-1}$ ) and potassium (9.24 and $2.99 \mathrm{~kg} \mathrm{ha}^{-1}$ ) removal over glyphosate and glufosinate ammoniumon 40 and 60 DAT, respectively. Higher NPK removal was obtained with control (28.63, 6.07 and $24.53 \mathrm{NPKkg} \mathrm{ha}^{-1}$, respectively on 40 DAT).

Among the weed management practices fallowed in transplanted rice, hand weeding twice on 25 and 45 DAT resulted significantly lower nitrogen (3.84 and $\left.2.97 \mathrm{~kg} \mathrm{ha}^{-1}\right)$, phosphorous (0.81 and $\left.0.63 \mathrm{~kg} \mathrm{ha}^{-1}\right)$ and potassium (3.29 and $2.55 \mathrm{~kg} \mathrm{ha}^{-1}$ ) removal by weeds on 40 and 60 DAT, respectively. Hand weeding twice resulted lesser NPK removal by weeds mainly due to completely removed all the weeds by hand weeding led to lesser weed dry weight and nutrient removal. This is in conformity with the findings of Subha lakshmi and Venkataramana (2008) indicated that hand weeding at 20 and 40 DAT recorded the lowest nutrient removal. However, this was comparable with pre emergence application of bensulfuron methyl + pretilachlor $660 \mathrm{~g} \mathrm{ha}^{-1}+$ post emergence application of bispyribac sodium $25 \mathrm{~g} \mathrm{ha}^{-1}$ and post emergence application of bispyribac sodium $25 \mathrm{~g} \mathrm{ha}^{-1}+$ hand weeding on 45 DAT. Pre emergence application of bensulfuron methyl + pretilachlor $660 \mathrm{~g} \mathrm{ha}^{-1}+$ hand weeding on 45 DAT recorded higher nitrogen (8.15 and 5.95 $\mathrm{kg} \mathrm{ha}^{-1}$ ), phosphorous (1.73 and $1.30 \mathrm{~kg} \mathrm{ha}^{-1}$ ) and potassium (6.98 and $5.10 \mathrm{~kg} \mathrm{ha}$ ) removal. Significantly more NPK was removed with unweeded control. In unweeded control, more weed dry weight and nutrient content in weeds resulted in higher removal of nutrients (NPK). This is in conformity with the findings of Parameswari and Srinivas (2014).

\section{Dry matter production (DMP)}

Among the pre plant herbicides, glyphosate $2.5 \mathrm{~kg} \mathrm{ha}^{-1}$ resulted significantly maximum dry matter production $\left(11517 \mathrm{~kg} \mathrm{ha}^{-1}\right.$ ) over control at maturity (Table 3). Application of glyphosate enriched the soil micro flora particularly bacteria, fungi and actinomycetes that fasten the decomposition of weeds and released the nutrient available for crop uptake and also provided good aeration to soil resulted higher DMP. The findings are in agreement with Nalini et al., (2012). It was comparable with glufosinate ammonium 1.0 $\mathrm{kg} \mathrm{ha}^{-1}\left(11467 \mathrm{~kg} \mathrm{ha}^{-1}\right)$ and halosulfuron methyl $67.5 \mathrm{~g} \mathrm{ha}^{-1}\left(10992 \mathrm{~kg} \mathrm{ha}^{-1}\right)$ at maturity. Lesser DMP was obtained with control plot (10273 kg ha ${ }^{-1}$ ).

In sub plots, hand weeding twice on 25 and 45 DAT produced significantly higher dry matter production (12075 kg ha-1) at maturity stage. However, this was comparable with pre emergence application of bensulfuron methyl 
+ pretilachlor $660 \mathrm{~g} \mathrm{ha}^{-1}+$ post emergence application of bispyribac sodium $25 \mathrm{~g} \mathrm{ha}^{-1}$ $\left(11896 \mathrm{~kg} \mathrm{ha}^{-1}\right)$ and post emergence application of bispyribac sodium $25 \mathrm{~g} \mathrm{ha}^{-1}+$ hand weeding on 45 DAT (11769 $\left.\mathrm{kg} \mathrm{ha}^{-1}\right)$. The combination of one herbicide followed by one manual weeding or two hand weeding effectively decreased the weed density, facilitated the crop to absorb more nutrients from soil and produce more photosynthates through expansion of leaf area which ultimately produce higher dry matter production. Pre emergence application of bensulfuron methyl + pretilachlor $660 \mathrm{~g} \mathrm{ha}^{-1}+$ hand weeding on 45 DAT recorded lesser dry matter production of $11308 \mathrm{~kg} \mathrm{ha}{ }^{-1}$. Significantly lesser dry matter production $\left(9263 \mathrm{~kg} \mathrm{ha}^{-1}\right)$ was obtained under unweeded check. Unweeded control plots registered lesser dry matter production due to uncontrolled weeds competed with essential resources like nutrient, water, light and space. These results are in corroboration with the findings of Gnanavel and Anbhazhagan (2010).

\section{Nutrient uptake by crop}

Nutrient uptake of transplanted rice was significantly altered by various pre plant and rice weed management measures (Table 3). Pre plant application of glyphosate $2.5 \mathrm{~kg} \mathrm{ha}^{-1}$ registered significantly higher nitrogen (124.6 $\mathrm{kg} \mathrm{ha}{ }^{-1}$ ), phosphorous (32.3 $\mathrm{kg} \mathrm{ha}^{-1}$ ) and potassium $\left(81.5 \mathrm{~kg} \mathrm{ha}^{-1}\right)$ uptake by cropthan halosulfuron methyl and control at maturity. However, this was on par with glufosinate ammonium $1.0 \mathrm{~kg} \mathrm{ha}{ }^{-1}$. Application of glyphosate $2.5 \mathrm{~kg} \mathrm{ha}^{-1}$ resulted in minimum number of weeds in transplanted rice, decomposition of dried weeds released the nutrients and also enhanced the microbial activity during initial stage would have improved the higher uptake of nutrient. Glufosinate also produced similar effect on nutrient uptake. This is in accordance with the findings of Prakash et al., (2013), who revealed that application of glyphosate $0.75 \mathrm{~kg}$ $\mathrm{ha}^{-1}$ at 15 days before crop establishment that effectively controlled the weed density led reduced nutrient removal and increased crop uptake. Halosulfuron methyl $67.5 \mathrm{~g} \mathrm{ha}^{-1}$ registered lower nitrogen $\left(110.9 \mathrm{~kg} \mathrm{ha}^{-1}\right)$, phosphorous $\left(28.8 \mathrm{~kg} \mathrm{ha}^{-1}\right)$ and potassium (72.9 $\mathrm{kg} \mathrm{ha}^{-1}$ ) uptake over glyphosate and glufosinate ammonium. Significantly lower NPK uptake was obtained with control (101.1, 26.0 and $65.5 \mathrm{~kg} \mathrm{NPK} \mathrm{ha}{ }^{-1}$, respectively at maturity stage).

Among the different weed management practices followed in transplanted rice, hand weeding twice on 25 and 45 DAT resulted significantly higher nitrogen (130.6 kg ha $\left.{ }^{-1}\right)$, phosphorous (33.8 kg ha ${ }^{-1}$ ) and potassium $\left(86.4 \mathrm{~kg} \mathrm{ha}^{-1}\right.$ ) uptake by crop at maturity. Manual weeding twice recorded higher nutrient uptake, mainly due to reduced weed dry weight as compared to unweeded control. This is in agreement with findings of Singh et al., (2005) who found that hand weeding on 20 and 40 days after sowing observed maximum nutrient uptake in rice.

Table.1

\begin{tabular}{|c|c|c|}
\hline Nutrient & Analytical method & References \\
\hline Nitrogen (N) & Microkjeldhal & Humphries (1956) \\
\hline Phosphorous (P) & Colorimetric estimation & Jackson (1973) \\
\hline Potassium (K) & Flame photometer & Jackson (1973) \\
\hline
\end{tabular}


Table.2 Effect of different weed management practices on total weed density $\left(\mathrm{m}^{-2}\right)$ and dry weight $\left(\mathrm{g} \mathrm{m}^{-2}\right)$ in transplanted rice.

\begin{tabular}{|c|c|c|c|c|}
\hline \multirow[t]{2}{*}{ Treatments } & \multicolumn{2}{|c|}{ Total weed density } & \multicolumn{2}{|c|}{ Total weed dry weight } \\
\hline & 40 DAT & 60 DAT & 40 DAT & $60 \mathrm{DAT}$ \\
\hline \multicolumn{5}{|c|}{ Main plots (Pre plant herbicides) } \\
\hline $\mathrm{M}_{1}$ - Glyphosate $2.5 \mathrm{~kg} \mathrm{ha}^{-1}$ & $4.02(18.1)$ & $3.68(16.7)$ & $3.55(14.5)$ & $3.49(15.0)$ \\
\hline $\mathrm{M}_{2}$. Glufosinate ammonium $1.0 \mathrm{~kg} \mathrm{ha}^{-1}$ & $4.88(28.3)$ & $4.61(25.0)$ & $3.87(18.1)$ & $3.77(17.2)$ \\
\hline $\mathrm{M}_{3}$. Halosulfuron methyl $67.5 \mathrm{~g} \mathrm{ha}^{-1}$ & $5.92(47.5)$ & $6.09(48.5)$ & $4.70(25.0)$ & $4.91(29.3)$ \\
\hline $\mathbf{M}_{4-}$ Control & $6.61(55.3)$ & $7.09(75.7)$ & $6.58(66.4)$ & $8.04(128.3)$ \\
\hline SEd & 0.15 & 0.23 & 0.15 & 0.26 \\
\hline $\mathrm{CD}(\mathrm{P}=\mathbf{0 . 0 5})$ & 0.39 & 0.57 & 0.38 & 0.64 \\
\hline \multicolumn{5}{|c|}{ Sub plots (Weed management in rice) } \\
\hline $\begin{array}{c}\mathrm{S}_{1} \text { - PE bensulfuron methyl + pretilachlor } 660 \mathrm{~g} \mathrm{ha}^{-1} \\
\text { + HW on } 45 \text { DAT }\end{array}$ & $5.38(29.2)$ & $4.49(21.0)$ & $4.33(18.9)$ & $3.70(13.8)$ \\
\hline $\mathrm{S}_{2}$ - POE bispyribac sodium $25 \mathrm{~g} \mathrm{ha}^{-1}+\mathrm{HW}$ on 45 DAT & $3.88(15.3)$ & $3.66(13.5)$ & $3.43(11.7)$ & $3.46(12.0)$ \\
\hline $\begin{array}{c}\mathrm{S}_{3} \text { - PE bensulfuron methyl + pretilachlor } 660 \mathrm{~g} \mathrm{ha}^{-1} \\
\text { + POE bispyribac sodium } 25 \mathrm{~g} \mathrm{ha}^{-1}\end{array}$ & $3.68(13.4)$ & $4.24(18.7)$ & $3.08(9.2)$ & $3.01(9.0)$ \\
\hline $\mathrm{S}_{4} . \mathrm{HW}$ on 25 and $45 \mathrm{DAT}$ & $3.41(11.8)$ & $3.07(9.4)$ & $2.99(8.9)$ & $2.60(6.9)$ \\
\hline $\mathrm{S}_{5}$ - Unweeded control & $10.44(116.8)$ & $11.37(144.9)$ & $9.55(106.4)$ & $12.13(195.4)$ \\
\hline SEd & 0.26 & 0.31 & 0.22 & 0.27 \\
\hline $\mathrm{CD}(\mathrm{P}=\mathbf{0 . 0 5})$ & 1.53 & 0.63 & 0.46 & 0.55 \\
\hline
\end{tabular}

The data were transformed to $\sqrt{X+0.5}$. The figures in the parenthesis are original values. $*$ Interaction non-significant

PE- Pre emergence POE- Post emergence HW- Hand weeding 
Table.3 Effect of different weed management practices on nutrient removal by weeds $\left(\mathrm{Kg} \mathrm{ha}^{-1}\right)$ in transplanted rice.

\begin{tabular}{|c|c|c|c|c|c|c|}
\hline \multirow[t]{2}{*}{ Treatments } & \multicolumn{2}{|c|}{ Nitrogen } & \multicolumn{2}{|c|}{ Phosphorous } & \multicolumn{2}{|c|}{ Potassium } \\
\hline & $40 \mathrm{DAT}$ & $60 \mathrm{DAT}$ & $40 \mathrm{DAT}$ & $60 \mathrm{DAT}$ & $40 \mathrm{DAT}$ & $60 \mathrm{DAT}$ \\
\hline \multicolumn{7}{|c|}{ Main plots (Pre plant herbicides) } \\
\hline $\mathrm{M}_{1}$. Glyphosate $2.5 \mathrm{~kg} \mathrm{ha}^{-1}$ & 6.25 & 6.47 & 1.33 & 1.37 & 5.36 & 1.73 \\
\hline $\mathrm{M}_{2}$. Glufosinate ammonium $1.0 \mathrm{~kg} \mathrm{ha}^{-1}$ & 7.80 & 7.41 & 1.65 & 1.57 & 6.69 & 2.11 \\
\hline $\mathrm{M}_{3}$ - Halosulfuron methyl $67.5 \mathrm{~g} \mathrm{ha}^{-1}$ & 10.78 & 12.63 & 2.29 & 2.68 & 9.24 & 2.99 \\
\hline $\mathrm{M}_{4-}$ Control & 28.63 & 55.31 & 6.07 & 11.73 & 24.53 & 17.94 \\
\hline SEd & 0.90 & 1.81 & 0.23 & 0.34 & 1.07 & 1.49 \\
\hline CD $(\mathbf{P}=\mathbf{0 . 0 5})$ & 2.10 & 3.90 & 0.51 & 0.90 & 2.20 & 3.00 \\
\hline \multicolumn{7}{|c|}{ Sub plots (Weed management in rice) } \\
\hline $\begin{array}{l}\mathrm{S}_{1} \text { - PE bensulfuron methyl + pretilachlor } 660 \mathrm{~g} \mathrm{ha}^{-1} \\
+ \text { HW on } 45 \text { DAT }\end{array}$ & 8.15 & 5.95 & 1.73 & 1.30 & 6.98 & 5.10 \\
\hline $\mathrm{S}_{2}$. POE bispyribac sodium $25 \mathrm{~g} \mathrm{ha}^{-1}+\mathrm{HW}$ on 45 & 5.04 & 5.17 & 1.07 & 1.10 & 4.32 & 4.43 \\
\hline $\begin{array}{c}\mathrm{S}_{3} \text { - PE bensulfuron methyl + pretilachlor } 660 \mathrm{~g} \mathrm{ha}^{-1} \\
\text { + POE bispyribac sodium } 25 \mathrm{~g} \mathrm{ha}^{-1}\end{array}$ & 3.97 & 3.88 & 0.84 & 0.82 & 3.40 & 3.32 \\
\hline $\mathrm{S}_{4}$ - HW on 25 and 45 DAT & 3.84 & 2.97 & 0.81 & 0.63 & 3.29 & 2.55 \\
\hline$S_{5}$. Unweeded control & 45.87 & 84.24 & 9.72 & 17.86 & 39.31 & 72.19 \\
\hline SEd & 1.13 & 1.97 & 0.33 & 0.40 & 1.57 & 1.70 \\
\hline $\mathrm{CD}(\mathrm{P}=0.05)$ & 2.70 & 4.0 & 0.70 & 1.11 & 3.20 & 3.60 \\
\hline
\end{tabular}

* Interaction non-significant $\quad$ PE- Pre emergence POE- Post emergence HW- Hand weeding 
Table.4 Effect of different weed management practices on nutrient uptake by crop $\left(\mathrm{Kg} \mathrm{ha}^{-1}\right)$, dry matter production $\left(\mathrm{Kg}^{-1}\right)$ and $^{-1}$ grain $^{-1}$ yield $\left(\mathrm{Kg} \mathrm{ha}^{-1}\right)$ in transplanted rice.

\begin{tabular}{|c|c|c|c|c|c|}
\hline \multirow[t]{2}{*}{ Treatments } & \multicolumn{3}{|c|}{ Nutrient uptake by crop at maturity } & \multirow[t]{2}{*}{ DMP } & \multirow[t]{2}{*}{ Grain yield } \\
\hline & Nitrogen & Phosphorous & Potassium & & \\
\hline \multicolumn{6}{|c|}{ Main plots (Pre plant herbicides) } \\
\hline $\mathrm{M}_{1}$. Glyphosate $2.5 \mathrm{~kg} \mathrm{ha}^{-1}$ & 124.6 & 32.3 & 81.5 & 11517 & 4232 \\
\hline$M_{2}$. Glufosinate ammonium $1.0 \mathrm{~kg} \mathrm{ha}^{-1}$ & 120.0 & 32.1 & 80.1 & 11467 & 4145 \\
\hline $\mathrm{M}_{3}$. Halosulfuron methyl $67.5 \mathrm{~g} \mathrm{ha}^{-1}$ & 110.9 & 28.8 & 72.9 & 10992 & 3959 \\
\hline $\mathbf{M}_{4-}$ Control & 101.1 & 26.0 & 65.5 & 10273 & 3565 \\
\hline SEd & 3.6 & 0.9 & 3.0 & 402 & 110 \\
\hline $\mathrm{CD}(\mathrm{P}=\mathbf{0 . 0 5})$ & 8.9 & 2.3 & 6.9 & 820 & 269 \\
\hline \multicolumn{6}{|c|}{ Sub plots (Weed management in rice) } \\
\hline $\begin{array}{c}\mathrm{S}_{1} \text { - PE bensulfuron methyl + pretilachlor } 660 \mathrm{~g} \mathrm{ha}^{-1} \\
+ \text { HW on } 45 \text { DAT }\end{array}$ & 111.6 & 28.8 & 70.8 & 11308 & 4143 \\
\hline $\mathrm{S}_{2}$. POE bispyribac sodium $25 \mathrm{~g} \mathrm{ha}^{-1}+\mathrm{HW}$ on 45 DAT & 127.3 & 33.0 & 83.7 & 11769 & 4327 \\
\hline $\begin{array}{c}\mathrm{S}_{3} \text { - PE bensulfuron methyl + pretilachlor } 660 \mathrm{~g} \mathrm{ha}^{-1} \\
\text { + POE bispyribac sodium } 25 \mathrm{~g} \mathrm{ha}^{-1}\end{array}$ & 128.7 & 33.3 & 84.8 & 11896 & 4299 \\
\hline $\mathrm{S}_{4} . \mathrm{HW}$ on 25 and 45 DAT & 130.6 & 33.8 & 86.4 & 12075 & 4187 \\
\hline$S_{5}$ - Unweeded control & 83.2 & 25.4 & 61.6 & 9263 & 2923 \\
\hline SEd & 5.1 & 1.2 & 3.0 & 652 & 101 \\
\hline $\mathrm{CD}(\mathrm{P}=\mathbf{0 . 0 5})$ & 10.4 & 3.0 & 7.1 & 1328 & 206 \\
\hline
\end{tabular}

* Interaction non-significant

PE- Pre emergence POE- Post emergence

HW- Hand weeding 
However, this was comparable with pre emergence application of bensulfuron methyl + pretilachlor $660 \mathrm{~g} \mathrm{ha}^{-1}+$ post emergence application of bispyribac sodium $25 \mathrm{~g} \mathrm{ha}^{-1}$ and post emergence application of bispyribac sodium $25 \mathrm{~g} \mathrm{ha}^{-1}+$ hand weeding on 45 DAT. Pre emergence application of bensulfuron methyl + pretilachlor $660 \mathrm{~g} \mathrm{ha}^{-1}+\mathrm{HW}$ on 45 DAT recorded lower nitrogen (111.6 kg ha-1), phosphorous (28.8 $\mathrm{kg} \mathrm{ha}^{-1}$ ) and potassium $\left(70.8 \mathrm{~kg} \mathrm{ha}^{-1}\right)$ uptake.

Significantly lesser NPK uptake was obtained with unweeded control. Occurrence of weed competition throughout the crop period in unweeded control resulted in higher nutrient removal by weeds and ultimately reduced the crop uptake. This is in line with the findings of Sridevi et al., (2015).

\section{Grain yield}

Grain yield of rice varied significantly with different weed control methods (Table 3). Among the pre plant herbicides, glyphosate $2.5 \mathrm{~kg} \mathrm{ha}^{-1}$ produced significantly higher grain yield (4232 $\mathrm{kg} \mathrm{ha}^{-1}$ ) over halosulfuron methyl and control. The increment in grain yield was mainly due to that application of glyphosate $2.5 \mathrm{~kg} \mathrm{ha}^{-1}$ at 15 days before puddling controlled all the weeds including Cyperus by inhibiting 5-enolpyruvylshikimate-3phosphate (EPSP) synthase pathway that required for protein synthesis. These conditions favoured better crop growth and yield parameters which ultimately increased the grain yield of rice. These results are similar with findings of Veeraputhiran and Balasubramanian (2010), who reported that application of glyphosate at 15 days before transplanting registered higher grain yield of rice. However, this was comparable with glufosinate ammonium $1.0 \mathrm{~kg} \mathrm{ha}^{-1}(4145 \mathrm{~kg}$ $\mathrm{ha}^{-1}$ ). Glufosinate inhibited the activity of glutamine synthase, the enzyme that essential for conversion of glutamate plus ammonium to glutamine. Accumulation of ammonia in the plant, that leads to destroys cells directly and inhibits photosystem I and II reactions, caused complete drying of weeds including Cyperus within 5 days after application, resulted in less weed density and competition favoured better crop growth and yield. Halosulfuron methyl $67.5 \mathrm{~g} \mathrm{ha}^{-1}$ resulted significantly lower grain yield $\left(3959 \mathrm{~kg} \mathrm{ha}^{-1}\right.$ ) than glyphosate and on par with glufosinate ammonium.The reason behind lesser grain yield was poor control of weeds particularly Cyperus rotundus. Halosulfuron methyl effectively control the Cyperus at 3-4 leaf stage only and in this experimental field, Cyperus was present in flowering to maturity stage. These findings are in accordance with Mritunjaykumar (2018), who reported that foliar application of halosulfuron methyl $75 \%$ WG was given at 34 leaf stage of Cyperus rotundus for effective control. Lesser grain yield (3565 $\mathrm{kg} \mathrm{ha}^{-1}$ ) was registered with control plot.

Among the post plant weed management practices, post emergence application of bispyribac sodium $25 \mathrm{~g} \mathrm{ha}^{-1}+$ hand weeding on 45 DAT registered significantly more grain yield (4327 $\mathrm{kg} \mathrm{ha}^{-1}$ ) over control. However, this was comparable with bensulfuron methyl + pretilachlor $660 \mathrm{~g} \mathrm{ha}^{-1}+$ bispyribac sodium $25 \mathrm{~g} \mathrm{ha}^{-1}$ on 25 DAT (4299 $\mathrm{kg} \mathrm{ha}^{-1}$ ), hand weeding twice on 25 and 45 DAT $(4187 \mathrm{~kg}$ $\left.\mathrm{ha}^{-1}\right)$ and pre emergence application of bensulfuron methyl + pretilachlor $660 \mathrm{~g} \mathrm{ha}^{-1}$ on 3 DAT + hand weeding on 45 DAT (4143 $\left.\mathrm{kg} \mathrm{ha}^{-1}\right)$. The combination of two herbicides or one herbicide followed by one manual weeding controlled the weeds both first flush as well as later emerged weeds. This corroborates with the findings of Suresh kumar and Durairaj (2016). Bispyribac sodium $25 \mathrm{~g} \mathrm{ha}^{-1}$ interfered with production of a plant enzyme necessary for growth and development named acetolactate synthase (ALS) led to effectively controlled the emerged weeds during critical stages and 
maintain the crop free from crop weed competition resulted in lesser competition by weeds for nutrients, space and light ultimately increased plant height, tiller number, productive tillers, filled grains, DMP, LAI and finally grain yield. These results are in line with findings of Prashanth et al., (2015) who reported that post emergence application of bispyribac sodium at $25 \mathrm{~g} \mathrm{ha}^{-1}$ at 15 DAT recorded significantly higher grain yield in transplanted rice. Lesser grain yield $(2923 \mathrm{~kg}$ $\mathrm{ha}^{-1}$ ) was recorded under unweeded control. Unweeded control registered lower grain yields. This is mainly because of severe crop weed competition during throughout the crop period. Similar findings were reported by Parthipan and Subramanian (2013).

Hence, it could be concluded from the field study, pre plant application of glyphosate 2.5 $\mathrm{kg} \mathrm{ha}^{-1}$ at 15 days before puddling followed by hand weeding twice on 25 and 45 DAT or post emergence application of bispyribac sodium $25 \mathrm{~g} \mathrm{ha}^{-1}$ on 15 DAT + hand weeding on 45 DAT found lesser nutrient removal by weeds, higher nutrient uptake by crop and higher grain yield in transplanted rice. However, increasing labourer cost and scarcity of labourer during critical period of agricultural operation lead to the search for alternative methods. In this context, pre plant application of glyphosate $2.5 \mathrm{~kg} \mathrm{ha}^{-1}$ at 15 days before puddling followed by post emergence application of bispyribac sodium $25 \mathrm{~g} \mathrm{ha}^{-1}$ on 15 DAT + hand weeding on 45 DATfound cost effective, lesser nutrient removal by weeds, higher nutrient uptake by crop and higher grain yield in transplanted rice.

\section{References}

Anonymous, 2018. Government of India (GoI). Agricultural Statistics at a Glance. Doctoral dissertation, Ministry of Agriculture. http://agricoop.gov.in/sites/default files/ agristatglance2018.pdf.
Anonymous, 2019. Area and production of cereals, Department of Economics and Statistics. https://eands.dacnet.nic.in/.

CPG, 2012. Crop Production Guide, Department of Agriculture, Govt. of Tamil Nadu, Chennai and Tamil Nadu Agricultural University, Coimbatore. pp. 4-43.

Ellis, M. J., L. J. Griffin, D. S. Linscombe and Webster P. E. 2003. Rice (Oryza sativa) and corn (Zea mays) response to simulated drift of glyphosate and glufosinate. Weed Technology. 17 (3): 452-460.

Gnanavel, I., and Anbhazhagan, R. 2010. Bioefficacy of pre and post emergence herbicides in transplanted aromatic basmati rice. Research Journal of Agricultural Sciences. 1 (4): 315-317.

Kumar, M., 2018. Halosulfuron Methyl 75\% WG (Sempra) - A New Herbicide for the Control of Cyperus rotundus in Maize (Zea mays L.) Crop in Bihar. International Journal of Current Microbiology and Applied Sciences. 7 (3): 2319-7706.

Nalini, K., P. Murali Arthanari and Chinnusamy, C. 2012. Early post emergence herbicidal weed management in transplanted rice. Proceedings of the Biennial Conference of Indian Society of Weed Science on "Weed threat to agriculture, biodiversity and environment", April.

Nivetha, C., G. Srinivasan and Shanmugam, P. M. 2017. Effect of Weed Management Practices on Growth and Economics of Transplanted Rice under Sodic Soil.. International Journal of Current Microbiology and Applied Sciences. 6 (12): 1909-1915.

Panse, V. G., and Sukhatme, P. V. 1967. Statistical methods for agricultural workers. Indian Council for Agricultural Research. New Delhi, India.

Parameswari, Y. S., and Srinivas, A. 2014. Influence of weed management practices on nutrient uptake and productivity of rice under different methods of crop establishment. Journal of Rice Research. 7 (1): 77.

Parthipan, T., and Subramanian, E. 2013. Rice and its Residual Effect on Succeeding 
Black gram. Journal of Agronomy. 12 (2): 99-103.

Prakash, C., R. K. Shivran and Koli, N. R. 2013. Bioefficacy of new herbicides in transplanted rice. Indian Journal of Weed Science. 45 (4): 282-284.

Prashanth, R., K. N. Kalyan murthy, M. Murali, C. Ramachandra and Sunil C. M. 2015. Growth and yield of transplanted rice as influenced by application of bispyribac sodium $10 \mathrm{SC}$ a post-emergence herbicide. International Journal of Tropical Agriculture. 33 (1): 37-40.

Ramachandra, C., N. Shivakumar and Ningaraju, G. K. 2014. Effect of herbicides and their combination on weed dynamics in rice-based cropping system. Indian Journal of Weed Science. 46 (2): 123-125.

Revathi, M., K. Annadurai and Chinnusamy, C. 2017. Effect of various pre and post emergence herbicides on crop yield and weed dynamics under different rice establishment methods in Sodic soil environment. International Journal of Chemical Studies. 5 (5): 1531-1536.

Singh, P. V., G. Singh and Singh, M. 2005. Effect of Bensulfuron-methyl (Londax 60 DF) on sedges and non-grassy weeds in transplanted rice. Indian Journal of Weed Science. 37 (1\&2): 40-44.

Soe thura., 2010. Evaluation of Weed Management practices in the System of Rice Intensification (SRI). M.Sc. (Ag.) Thesis, Department of Agronomy, Yezin
Agricultural University, Yezin, Nay Pyi Taw.

Sridevi, S., M. Venkata Ramana, K. Suresh and Madhavi, M. 2015. Nutrient depletion by weeds, yield and economics of rice as influenced by weed management. Proceedings of 25th Asian-Pacific Weed Science Society Conference on "Weed Science for Sustainable Agriculture, Environment and Biodiversity", Hyderabad, India during 13-16, October. pp. 100.

Subha Lakshmi, C., and Venkataramana, M. 2008. Effect of different weed management practices on growth, nutrient uptake by transplanted rabi rice and weeds. Crop research. 35(3): 165-168.

Suresh kumar, R., and Durairaj. 2016. Weed characters and indices of transplanted rice as influenced by different weed management practices. International Journal of Agriculture Sciences. 8 (51): 2221-2223.

Veeraputhiran, R., and Balasubramanian, R. 2010. Evaluation of new post emergence herbicide in transplanted rice. Proc. National Conference on Challenges in Weed Management in Agro ecosystem: Present Status and Future Strategies. Coimbatore, India. 30 (175).

Veeraputhiran, R., and Balasubramanian, R. 2013. Evaluation of bispyribac-sodium in transplanted rice. Indian Journal of Weed Science. 45 (1): 12-15.

\section{How to cite this article:}

Manisankar, G., T. Ramesh and Rathika, S. 2021. Effect of Different Weed Management Practices on Nutrient Removal, Nutrient Uptake and Grain Yield of Transplanted Rice (Oryza sativa L.) under Sodic Soil Ecosystem. Int.J.Curr.Microbiol.App.Sci. 10(05): 378-389. doi: https://doi.org/10.20546/ijcmas.2021.1005.045 